\title{
Młodziė̇, internet, socjalizacja \\ - w perspektywie współczesnych \\ paradygmatów społecznych
}

DOI: $10.47050 / 65591777.14-39$

Marek Konopczyński, Filip Konopczyński

W artykule podjęto próbę opisania dominujących w naukach społecznych dyskursów, dotyczących nowych zjawisk socjalizacyjnych związanych z powstaniem oraz upowszechnieniem technik komputerowych i sieciowych. Autorzy prezentują główne paradygmaty stosowane do opisu zjawisk socjalizacyjnych i badają ich użyteczność w analizowaniu procesów wywołanych zmianą technologiczną. Charakteryzują także wpływ nowych praktyk kulturowych na sfery związane z emocjami, agresją i strategiami tworzenia tożsamości przez młode osoby.

\section{Słowa kluczowe:}

\section{internet}

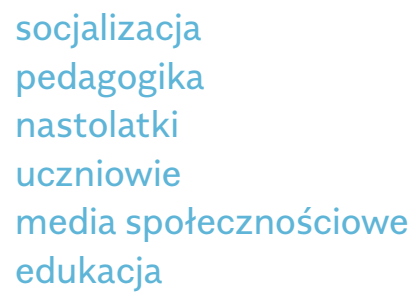




\section{Internet, socialisation and the youth \\ - the perspective of contemporary social paradigms}

DOI: $10.47050 / 65591777.14-39$

Marek Konopczyński, Filip Konopczyński

The article attempts to describe the dominant social science's discourses related to the phenomena of youth socialization into internet-mediated environment. The authors present major paradigms conceptualizing new forms of socialization and examine their validity and usefulness in analyzing processes induced by the ongoing technological revolution. In the second part the article examines the impact of new cultural practices on spheres associated with emotions, aggression and personal identity-creation strategies among the contemporary youth.

\section{Keywords:}

internet

youth

socialisation

pedagogics

education

students

social media 


\section{Paradygmaty nauk społecznych i pedagogicznych wobec socjalizacji $w$ internecie}

Problem funkcjonowania młodych ludzi w przestrzeni internetu jest równie wielowątkowy i złożony, jak całość procesów psychofizycznego oraz społecznego rozwoju człowieka, i choćby z tego powodu należy wystrzegać się uproszczeń, generalizacji i wysuwania pochopnych wniosków. Ze względu na rangę problemu i skalę zainteresowania, wielu badaczy, dążąc do uzyskania odpowiedzi na stawiane pytania, udziela ich często na podstawie badań cząstkowych i nie zawsze popartych najwyższą metodologiczną starannością. Nie chcąc iść tą drogą, autorzy niniejszego artykułu podejmują próbę zaprezentowania najnowszego stanu dyskusji eksperckiej w obszarze związanym z uspołeczniającymi aspektami współczesnego internetu, skupiając się na kilku charakterystycznych dla tego procesu skutkach. W pierwszej części omówiono wnioski płynące z badań i analiz dotyczących socjalizacyjnych funkcji internetu w odniesieniu do popularnych (na przykład w mediach) przekazów na ten temat. W drugiej części szczegółowo przedstawiono trzy problemy teoretyczne związane z uspołeczniającymi funkcjami internetu w odniesieniu do empatii, agresji i mechanizmów autoprezentacyjnych.

Zaprezentowane refleksje mają charakter teoretyczny i syntetyczny, a ich zadaniem jest ukazanie zmian w procesach socjalizacyjnych wywołanych przez powstanie i popularyzację internetu oraz technologii komputerowych. Do niedawna wspomniane zmiany przebiegały wyłącznie w środowisku naturalnym lub - w populacji osób bardziej zaawansowanych technologicznie - przy udziale mediów znacznie mniej angażujących dzieci psychofizycznie (druk, radio, telewizja). W porównaniu z innymi środkami przekazu internet jest "mocniejszy" - także w tym sensie, że wymyka się kontroli: trudniej jest nadzorować to, jak długo i w jaki sposób się z niego korzysta. Z punktu widzenia rodzica lub opiekuna o wiele łatwiej jest na przykład sprawdzać, jak długo ktoś ogląda telewizję, niż ograniczyć dostęp do smartfona lub sprzętu komputerowego.

Myślenie pedagogiczne, kształtujące postrzeganie otaczającego świata społecznego i zachodzących w nim procesów społeczno-wychowawczych (w tym funkcjonowania w sieci), oparte jest na określonych paradygmatach. Rozumiemy przez to zbiór ogólnych przesłanek w wyjaśnianiu obszaru rzeczywistości, przyjęty przez przedstawicieli 
danej dyscypliny naukowej jako wzór ostatecznego myślenia. Minione stulecie było zdominowane przez kilka paradygmatów społeczno-pedagogicznych, które wywarły największy wpływ na nasze postrzeganie złożonej sytuacji wychowawczo-socjalizacyjnej młodego pokolenia, tym samym również na praktykę wychowawczą. Powstanie internetu postawiło przed teoretykami i praktykami wychowania nowe wyzwania. Aby móc je podjąć, potrzebne jest przeanalizowanie zasadności posługiwania się dotychczas dominującymi modelami - nie po to, aby je bezwzględnie porzucić, na przykład na rzecz zyskujących coraz większą popularność teorii sieciowych, takich jak teoria aktora-sieci Brunona Latoura (2005), ale żeby ocenić ich przydatność w obliczu szerokich uwarunkowań cywilizacyjnych.

Paradygmat humanistyczny wywodzi się z nominalizmu i woluntaryzmu, a więc subiektywizmu naukowego, i koncentruje się na indywidualnym znaczeniu życia społecznego. Prezentuje krytyczne stanowisko wobec kultury jako zbioru faktów narzucanych człowiekowi odgórnie, z zewnątrz, zazwyczaj bezalternatywnie. Według tego nurtu myślenia człowiek ma prawo do stanowienia zasad i realnego wpływu na kulturę oraz interpretowania konfliktów społecznych z punktu widzenia ochrony interesu jednostki.

Podobne założenia przyjmuje paradygmat interpretatywny, który również zakłada subiektywizm naukowy, odrzucając (tak jak paradygmat humanistyczny) porządek deterministyczny, zajmując się rozwojem świadomości jednostek funkcjonujących w ramach struktur społecznych. Przedmiotem paradygmatu interpretatywnego jest subiektywne rozumienie doświadczenia społecznego przez testowanie konkretnych zbiorowości ludzkich.

Paradygmat strukturalistyczny z kolei wywodzi się z realizmu i determinizmu, a więc obiektywizmu naukowego, i zakłada istnienie obiektywnie i ponadjednostkowo doświadczanych struktur, według których funkcjonuje życie społeczne. Każda jednostka przyporządkowana jest określonej strukturze i poddana oddziaływaniu sił determinujących jej los. Strukturalizm bada zakładane konflikty społeczne z punktu widzenia organizacji (struktur) społecznych.

Wywodzący się z realizmu i determinizmu paradygmat funkcjonalistyczny ujmuje świat społeczny podobnie - jako obiektywny byt z gotowymi strukturami regulującymi życie jednostki. Formą opisu świata jest system kulturowy podporządkowujący sobie osobowości jednostek. 
Jest w pewnym sensie paradygmatem homeostazy społecznej, uznającym, że występowanie nierówności społecznych to cena utrzymania równowagi całości systemu.

$\mathrm{Na}$ tych podstawach powstały dwie tendencje budowania teorii pedagogicznych. Pierwsza to pajdocentryzm, którego jest celem nieskrępowany rozwój dziecka (paradygmat humanistyczny), preferujący świadome, radykalne działania wzmacniające jego rozwój i usuwające społeczne blokady podczas tego procesu (antypedagogika, pedagogika postmodernizmu) oraz działania świadome regulujące i wzmacniające u dziecka rejestry subiektywnych znaczeń nadawanych otaczającej rzeczywistości (paradygmat interpretatywny), takie jak pedagogika personalistyczna, pedagogika religii.

Przeciwstawieniem tej tendencji jest didaskalocentryzm, mieszczący się w paradygmacie strukturalistycznym i funkcjonalistycznym, a polegający na świadomych i radykalnych działaniach kształtujących osobowość dziecka zdolną do działania w warunkach strukturalnych konfliktów (pedagogika herbartowska, pedagogika pozytywistyczna) oraz działaniach kształtujących osobowość dziecka zgodnie ze standardami psychologiczno-społecznymi obowiązującymi w danej kulturze.

Efektem ścierania się wspomnianych wizji są dwa podstawowe nurty myślenia o pedagogice - jako teorii i jako praktyce społecznej. Pierwszym z nich jest pedagogika neopozytywistyczna, drugim - pedagogika kultury. Pedagogika neopozytywistyczna sięga do dorobku „nauczania wychowującego" Johanna Friedricha Herbarta, opartego na determinizmie psychologicznym (behawioryzm) i determinizmie socjologicznym (Auguste Comte), oraz dorobku Émile'a Durkheima (określenie teoretycznych i praktycznych uwarunkowań relacji między jednostką a społeczeństwem). Pedagogika kultury uznaje i preferuje kształcenie oraz wychowywanie jednostki przez jej kontakty z obiektywnymi dobrami kultury. Nastawiona jest na hermeneutykę, a więc na pogłębione interpretacje i rozumienie symboli przez ujmowanie różnych oddziaływań edukacyjno-wychowawczych (wychowania estetycznego, etycznego, artystycznego) jako pedagogicznego stymulowania wpływu wartości kulturowych na kształtowanie się ludzkiej osobowości. W pewnym sensie stała się obroną pedagogiki przed orientacjami stricte scjentystycznymi, naturalistycznymi, materialistycznymi.

Współczesne koncepcje w polskiej pedagogice (Śliwerski 2012) sięgają coraz mocniej do wizji pajdocentrycznych, opartych na pa- 
radygmatach humanistycznym i interpretatywnym. Ta podstawowa różnica w teoretycznym podejściu do problemu, skutkująca nowymi rozwiązaniami metodycznymi, wywołuje żywe polemiki i dyskusje w środowiskach naukowych, ale przede wszystkim budzi niepokój i liczne wątpliwości w środowiskach wychowawców praktyków. Dlatego warto bliżej przyjrzeć się temu problemowi.

Sensem każdej działalności edukacyjno-wychowawczej jest młody człowiek, przedmiotem zaś - jego dobro. Należy to pojęcie rozumieć bez odcieni kontekstowych i interpretacyjnych. Dobrem każdego człowieka jest jego rozwój, który umożliwia mu pokonywanie przeciwieństw losu w taki sposób, aby za każdym razem patrząc w przyszłość, widział otwierające się przed nim społeczne perspektywy. Wymienione odniesienia łączy kultura socjalizacyjna i wychowawcza.

Podstawą każdej kultury socjalizacyjnej, szczególnie wychowawczej, są wartości i normy. Dają one ludziom poczucie sensu i stanowią zespół wskazówek postępowania. Od poziomu stopnia ich przyswojenia oraz umiejętności właściwego stosowania zależy jakość naszej egzystencji. Warunki socjalizacyjno-kulturowe towarzyszące ludziom od urodzenia wpływają na ich zachowania, nie pozbawiając ich równocześnie indywidualności i spontaniczności (Giddens 2006). To właśnie kultura socjalizacyjna współtworzy najważniejsze parametry naszej tożsamości, umożliwiając nam samorealizację w odgrywanych rolach społecznych. Tożsamość jednostkowa i społeczna określają istotę rozumienia zarówno nas samych, jak i innych ludzi. Przez parametry tożsamości osobowej potrafimy lepiej rozumieć siebie, a dzięki parametrom tożsamości społecznej jesteśmy rozumiani przez innych. Kultura socjalizacyjna i wychowawcza, przede wszystkim wynikające z niej twórcze rozwiązywanie sytuacji problemowych, umożliwiają zindywidualizowanie ludzkiego losu i wyposażają człowieka w możliwości twórcze. Kultura, kreatywność i twórczość stanowią kluczowe społeczne wyznaczniki rozwoju człowieka i jednocześnie określają główne parametry jego tożsamości jednostkowej oraz społecznej. Treść tych pojęć buduje wewnętrzną intelektualną przestrzeń człowieka i wpływa na jego role życiowe.

Rozważania teoretyczne należy uzupełnić o nowe wątki związane z rosnącą popularnością inspirowanych rozwojem cybernetyki podejść opartych na teorii sieci (Latour 2006; Castells 1996). Nie odnoszą się one wprost do problematyki wychowania, pedagogicznych aspektów socjalizacji czy zmiany norm społecznych, zapewniają jednak trudne 
do przecenienia nawiązania dotyczące sposobu dystrybucji informacji, a co za tym idzie - także kulturowych wzorców zachowań i, co szczególnie istotne, przekonująco tłumaczą problemy, z którymi borykają się dziś nauki społeczne i humanistyczne. Stosowanie analiz opartych na badaniu sieci komunikacyjnych pozwala w wielu wypadkach uchwycić na przykład skalę zmian społecznych, prawdziwy zakres zjawiska, a nawet analizować sentymenty użytkowników. Zwraca ponadto uwagę na znaczenie infrastruktury komunikacyjnej, w której - zgodnie z proroczą intuicją Marshalla McLuhana - przekaźnik (także) jest przekazem, istotna jest również rola nie-ludzkich aktorów komunikacji oraz to, jak wchodzą z nimi w interakcje ludzie, co stanowi twórczy wkład w rozwój nauk społecznych.

Wraz ze zmianą sposobu reprodukcji wiedzy tradycyjne instytucje naukowe, edukacyjne i medialne mają coraz większy problem z nadążaniem za skalą zmian cywilizacyjnych zachodzących w związku z niskokosztową i błyskawiczną wymianą informacji. Zmiany następują często pod powierzchnią oficjalnych czynników publicznych i prywatnych, stawiając dotychczasowe instytucje przed trudnym wyborem: obrony status quo lub dostosowania się do trudnych do przewidzenia kierunków zmian społecznych.

Poszukiwania teoretycznych odwołań będących fundamentem rozważań dotyczących współczesnej (nowej) socjalizacyjnej "mocy” internetu, definiowanej $w$ ramach szerszych koncepcji niż klasycznie przywoływane, odbywają się w toku zaciekłych dyskusji i różnorodnych interpretacji dotyczących możliwości socjalizacyjno-wychowawczych, „rzeczywistości poszerzonej”, którą oferuje współczesne środowisko internetowe. Rodzi się uzasadnione pytanie: czy funkcjonowanie mechanizmów socjalizacji internetowej mieści się w dotychczasowym, klasycznym pedagogicznym myśleniu paradygmatycznym? Być może należałoby dokonać redefinicji obowiązujących paradygmatów pedagogicznych i określić nowe ich definicje.

Według danych Banku Światowego w 2016 r. z internetu korzystało już ponad $46 \%$ mieszkańców Ziemi ${ }^{1}$. Liderami w skali świata są Luksemburg, Kuwejt, Dania, Norwegia, Szwecja, Holandia i Japonia - w każdym z tych krajów liczba użytkowników sieci przekracza 
90\% obywateli (Polska z wynikiem $75 \%$ plasuje się powyżej średniej). Wśród osób młodych poziom użytkowników sieci jest wyższy od średniej - według International Telecommunication Union nawet o około $30 \%$ w porównaniu z całą populacją ${ }^{2}$. Oznacza to, że zapowiadana od początku lat dziewięćdziesiątych ubiegłego wieku rewolucja informacyjna już się dokonała w odniesieniu do młodych osób, a dorośli pozostają za nimi w tyle.

Dwadzieścia osiem lat od przekazania sieci informacyjnej do powszechnego użytku środowisko internetowe jest dziś powszechnym ekosystemem, w którym funkcjonują dzieci na całym świecie. Jak pokazują badania ilościowe (na przykład projekt "Global Kids Online LSE", prowadzony pod kierownictwem Sonii Livingstone ${ }^{3}$, lub polski raport Naukowej i Akademickiej Sieci Komputerowej z badania "Nastolatki 3.0"4), wiek inicjacji internetowej w ostatniej dekadzie znacznie się obniżył. Dziś z sieci przez wiele godzin dziennie korzystają już dzieci kilkuletnie. $Z$ antropologicznego punktu widzenia można więc mówić o rzeczywistym zaistnieniu globalnej kultury prefiguratywnej (Mead 1978), w której ton zmianom cywilizacyjnym nadają zachowania i postawy osób młodszych. Oczywiście nie dzieje się to całkowicie oddolnie - rozwiązania technologiczne i platformy aktywności dostarczają osoby dorosłe, szczególnie dysponujące odpowiednim kapitałem. Niemniej w ramach modelu cyfrowej gospodarki rynkowej to właśnie potrzeby i preferencje młodych konsumentów ustalają kierunki, za którymi musi podążać sektor prywatny, a także - co nie odbywa się bez problemów czy opóźnień - administracja publiczna.

Paradoks tej sytuacji polega na tym, że nie wiemy, jakie będą konsekwencje cyfrowej rewolucji, w której biorą udział młode pokolenia. Generacja "cyfrowych tubylców" (digital natives) Marca Prensky'ego (2001), która poznawała świat równolegle za pomocą tradycyjnych mediów i internetu, stosunkowo niedawno weszła w dorosłość. Jest to jeden z powodów, które uniemożliwiają przeprowadzenie na tym etapie definitywnej oceny wpływu technologii informacyjnych na kulturowy proces dorastania (od strony zarówno psychoemocjonalnej, jak i spo- 
łecznej, zawodowej i politycznej). Nie oznacza to jednak, że nie można podjąć próby nakreślenia kierunku zachodzących zmian.

Nie ma wątpliwości, że tak zwane pokolenia milenialsów (mimo braku powszechnej zgody można za nie uznać roczniki urodzone w latach 1980-1995) i pokolenie Y (urodzeni po 1995 r.) cechuje znaczna różnica deklarowanych wartości, postaw i oczekiwań w porównaniu z przedstawicielami poprzednich generacji. Dowodzi tego między innymi raport Deloitte Millennial Survey (2018), w którym badano młodych obywateli kilkudziesięciu krajów świata. Jedna z ciekawych statystyk dotyczy społecznego prestiżu, który jest postrzegany przez młodych ludzi inaczej niż w poprzednich pokoleniach. Przywódcy religijni i polityczni cieszą się wśród nich znacznie niższym szacunkiem nie tylko niż liderzy i liderki społeczeństwa obywatelskiego, ale także szefowie i szefowe prywatnych przedsiębiorstw.

Patrząc na to zjawisko z punktu widzenia nauk społecznych, wyniki te można zinterpretować jako wotum nieufności wobec tradycyjnych autorytetów i kierowanych przez nie instytucji. Niezależnie od czynników socjoekonomicznych - dorastania, szczególnie w krajach Zachodu w czasach globalnego kryzysu finansowego i w dobie postępujących nierówności ekonomicznych ${ }^{5}$ - to, co wyraźnie różni dzisiejsze młodsze pokolenia od ich rodziców i dziadków, to otoczenie medialne, w którym dorastają. Rewolucja informacyjna i upowszechnienie się komputerów spowodowało, że rolę głównego medium pośredniczącego w poznawaniu i adaptowaniu się do świata przez młodych ludzi odgrywają dziś nie książki, prasa, radio czy telewizja, ale internet. To, że dzieci od najmłodszych lat poznają świat za pośrednictwem interaktywnego, multimedialnego otoczenia informacyjnego, ma duże znaczenie dla procesu socjalizacji, a co za tym idzie - wytwarzania tożsamości społecznej. To wyzwanie, przed którymi stoją nie tylko rodzice, ale przede wszystkim instytucje, przede wszystkim edukacyjne.

W naszych rozważaniach dotyczących wybranych tożsamościowych konsekwencji działania mechanizmów socjalizacyjnych w "rzeczywistości poszerzonej" (wirtualnej) szczególnie interesujący jest wpływ mediów społecznościowych (nieograniczonych tylko do portali) na postrzeganie siebie w wymiarze relacji społecznych. 
Mówiąc o uspołeczniających funkcjach internetu, należy podkreślić, że wiążą się one z zastosowaniami komunikacyjno-technologicznymi sieci, dzięki którym użytkownicy wchodzą między sobą w interakcję. Historycznie to właśnie platformy umożliwiające międzyludzkie kontakty (poczta e-mail, czaty, fora dyskusyjne, aplikacje i programy do komunikacji: MSN czy Gadu-Gadu) stanowiły pierwsze masowe zastosowanie sieci - najpierw w skali kontynentalnej (Ameryka Północna, Europa), a następnie globalnej. Na użytek niniejszego artykułu nie będą więc poruszane kwestie związane z całością infrastruktury informacyjnej sieci, które - szczególnie w ramach tak zwanej czwartej rewolucji przemysłowej (Schwab 2016): internet rzeczy, big data, inteligentne urządzenia - stanowią coraz większą część światowego transferu informacji. Zagadnienie pośredniego wpływu usieciowienia otaczających nas rozwiązań technologicznych (na przykład kontaktujące się między sobą bez wiedzy użytkowników urządzenia gospodarstwa domowego, autonomiczne boty) jest bardzo interesujące, wydaje się jednak, że ze względu na obecną skalę jego występowania jest jeszcze za wcześnie, aby wypowiadać się na ten temat autorytatywnie i wyciągać ogólne wnioski z punktu widzenia procesu uspołecznienia w ramach globalnej sieci.

Raport UNICEF Children in the digital world (2017) podejmuje ambitną próbę opisania problematyki związanej z wpływem technologii cyfrowych na rozwój dzieci i młodzieży. Według autorów dostęp do internetu jest prezentowany jako narzędzie umożliwiające indywidualny rozwój uczniów, a co za tym idzie - krajów, z których pochodzą. Punktem wyjścia jest uznanie konieczności dostosowania systemów edukacyjnego i prawnego do wyzwań, które pojawiają się w związku z trwającą rewolucją cyfrową. Raport koncentruje się na szansach stwarzanych młodym ludziom przez internet i na zagrożeniach związanych z cyfrowymi nierównościami i wykluczeniem. Należy im zapobiec, aby w jak największym stopniu dzisiejsza młodzież mogła w przyszłości produktywnie funkcjonować w globalnej gospodarce i społeczeństwie.

We wspomnianym raporcie "ciemna strona internetu" opisana jest przede wszystkim przez pryzmat niewłaściwych dla dzieci treści, które można znaleźć w tej przestrzeni. Wśród zagrożeń wymieniono między innymi materiały o charakterze pornograficznym, nękanie, sieci pedofilskie oraz terrorystyczne, hazard i cyfrową inwigilację naruszającą prawo do prywatności. 
Kwestia tak zwanego problemowego użycia internetu (PUI) opisana jest przede wszystkim w kategoriach lęku wyrażanego przez rodziców i media. Autorzy twierdzą, że brakuje badań empirycznych potwierdzających znaczne w skali występowanie tak zwanego uzależnienia od internetu (sprzętu elektronicznego). Zamiast tego proponowana jest interpretacja, w której dzieci i młodzież uciekają w świat wirtualny z powodu problemów, z jakimi spotykają się w świecie realnym.

Wydany w tym samym roku przez UNICEF przegląd literatury eksperckiej (Kardefelt-Winther 2017) wskazuje, że z braku przekonujących dowodów empirycznych o negatywnym wpływie technologii cyfrowych na rozwój młodych ludzi nie należy ulegać lękom i ograniczać roli internetu w edukacji, a więc także socjalizacji osób w wieku szkolnym. Co więcej, autorzy tej publikacji powołują się na wiele obserwacji świadczących o pozytywnych skutkach wychowania w środowisku cyfrowym. Większe zdolności w zakresie multitaskingu (zdolność do wykonywania wielu czynności w tym samym czasie), szybsza zdolność reagowania na nowe informacje czy głębsze usieciowienie społeczne młodych to korzyści, które, w opinii autorów, przesądzają o pozytywnej ocenie wpływu technologii cyfrowych na rozwój dzieci. Należy zaznaczyć, że podejście prezentowane w raporcie wywołało pewne kontrowersje - wbrew deklaracjom autorów naukowcy wciąż nie doszli do konsensusu w sprawie oddziaływania internetu, szczególnie mediów społecznościowych, na psychikę dzieci i młodzieży (Sherman i in. 2011).

Rozwój i poszerzenie zakresu użytkowania internetu stworzył podstawy coraz większej personalizacji jego funkcjonalności przez użytkowników. Na tej fali na początku XXI w. na całym świecie zaczęły powstawać strony, portale i serwisy, które dziś nazywa się mediami społecznościowymi. Pierwsze pojawiły się serwisy takie jak LunarStorm i Myspace, jednak dopiero powstały w 2004 r. Facebook uzyskał dużą rozpoznawalność i w ciągu kilku lat stał się najpopularniejszym portalem społecznościowym świata (Edosomwan i in. 2011). Według oficjalnych danych w 2018 r. konto na portalu założyło 2,3 miliarda osób. Dziś to właśnie firma Marka Zuckerberga, obok Instagrama i Twittera, stanowi „wielką trójkę” platform umożliwiających użytkownikom szeroko rozumianą komunikację, dostęp do informacji czy (w ostatnim czasie) zakupy. Ze względu na gwałtowny wzrost popularności wśród 
dzieci fenomen „socmediów" szybko zwrócił uwagę rodziców6, mediów (Pogue 2008), urzędników (na przykład Najwyższej Izby Kontroli) czy organizacji międzynarodowych ${ }^{8}$. O ile jednak w zakresie korzystania przez dzieci z mediów społecznościowych panował rzeczywisty permisywizm, o tyle media często posługiwały się dyskursem epidemiologicznym w duchu „paniki moralnej". Sytuacja zmieniła się w ostatnich latach wraz z kolejnymi publikacjami psychologicznymi, socjologicznymi i pedagogicznymi.

Autorzy badania "Social Media Use and Children's Wellbeing" (McDool i in. 2016) potwierdzają, że częste korzystanie z mediów społecznościowych prowadzi u dzieci do pogorszenia samopoczucia, częstszego występowania zaburzeń i stanów lękowych oraz zwiększa podatność na depresję. Inni badacze (Wood i in. 2016) wskazują, że choć korzystanie z mediów społecznościowych może zmniejszać poczucie osamotnienia u dzieci i nastolatków, to regularne i częste korzystanie z nich wiąże się z wieloma negatywnymi skutkami psychicznymi i socjalizacyjnymi. Szukając wytłumaczenia tych wyników, wskazuje się trzy główne możliwe przyczyny:

$\rightarrow$ charakter interakcji w mediach społecznościowych, związany z ciągłym porównywaniem się z innymi, szczególnie z punktu widzenia idealizacji zachowań autoprezentacyjnych przez użytkowników,

$\rightarrow$ teorie "skończonych zasobów", argumentujące, że wzrost liczby godzin spędzanych przez młodzież w mediach społecznościowych powoduje, że poświęca ona mniej czasu na aktywności, które pozytywnie wpływają na rozwój i samopoczucie,

$\rightarrow$ częste występowanie w mediach społecznościowych zachowań przemocowych, na przykład cyberbullyingu, treści ofensywnych czy nielegalnych. Im więcej czasu spędzonego w sieci, tym większa szansa na zostanie celem ataku, co prowadzi do negatywnych skutków dla psychiki. Podejście to koncentruje się na przestrzeni sieciowej jako miejscu częstszego niż w świecie realnym występowania zachowań agresywnych i treści szkodliwych. i młodzieży (2016). 
Należy pamiętać, że interpretacje te nie mają charakteru rozłącznego i składają się na wielowymiarową charakterystykę środowiska mediów społecznościowych.

\section{Empatia, agresja, autoprezentacje, czyli emocje w socjalizacyjnych interakcjach internetowych}

Zmiana środowiska społecznych interakcji spowodowana przez rozwój technologii komunikacyjnych w ramach globalnej sieci wpływa także na modyfikację w istotnym stopniu warunków brzegowych, które dotychczas traktowano jako naturalne elementy socjalizacji dzieci i młodzieży. Możemy określić sześć kluczowych czynników implikujących jakość socjalizacyjną kontaktów internetowych:

$\rightarrow$ Anonimowość i pseudonimowość w części interakcji w sieci. Wraz z postępem technologii uczenia maszynowego i rozwojem sztucznej inteligencji zmniejsza się pewność, czy użytkownik wchodzi w interakcję z człowiekiem, czy z maszyną.

$\rightarrow$ Zmiana dotychczasowych reguł budowania hierarchii społecznej-obecnie odbywa się to na podstawie popularności i zasięgu, zdobywanych za pomocą kanałów internetowych. Lajki, wyświetlenia czy subskrypcje tworzą nowy system dystrybucji społecznego prestiżu, który często przekłada się nie tylko na akceptację i popularność, ale także na wymierne korzyści finansowe.

$\rightarrow$ Poczucie bliskości z resztą świata - w mediach społecznościowych wchodzimy w interakcję z obcymi osobami, tak jakby były naszymi znajomymi. Informacje $z$ dowolnego miejsca na Ziemi docierają do nas w czasie rzeczywistym.

$\rightarrow$ Internet oferuje grupy wsparcia w niemal dowolnym obszarze: wpadając w taką "bańkę informacyjną", można łatwo uwierzyć, że osób "takich jak ja” jest mnóstwo, co może zaburzyć obraz rzeczywistości społecznej w sytuacji, gdy chodzi o zjawiska w istocie rzadkie.

$\rightarrow$ Częstotliwość występowania zaburzeń, na przykład uzależnienia od wieloosobowych gier online, pokazuje, że co najmniej część użytkowników sieci przejawia podatność na zachowania szkodliwe z punktu widzenia rozwojowego.

$\rightarrow$ Łatwość dostępu do treści nielegalnych i szkodliwych jest wyższa, a realne możliwości kontroli mniejsze niż dotychczas. 
Wspomniane czynniki są pozornie zbliżone do zjawisk występujących w socjalizacyjnym środowisku naturalnym. Podobieństwa dotyczą treści interakcji, a różnice uwidaczniają się w formie interakcji. W środowisku internetu istnieje realna możliwość zachowania anonimowości podczas interakcji, co jest niemożliwe w środowisku naturalnym. Podobnie jest w innych aspektach wymienionych powyżej - przez możliwości technologiczne komputerów i internetu pewne formy naturalnych ludzkich skłonności nabierają w sieci nowego charakteru. Dlatego w dalszych rozważaniach zasygnalizujemy kilka wybranych problemów dotyczących emocji w relacjach internetowych i ich skutków wizualizacyjnych, jakimi są dokonywane autoprezentacje w sieci. Chcemy się skrótowo skupić na trzech zagadnieniach: empatii, agresji i autoprezentacjach społecznych w sieci. Tym problemom w zasadzie nie poświęca się miejsca w literaturze pedagogicznej, a przecież stanowią one istotny czynnik determinujący formę i treść funkcjonowania młodych ludzi w środowisku internetowej rzeczywistości poszerzonej.

Jednym z przedmiotów interesujących badaczy internetu jako środowiska socjalizującego jest jego wpływ na postawy empatyczne użytkowników. Zintensyfikowane kontakty dzieci zapośredniczone przez internet miały, w opinii krytyków, tworzyć warunki, w których najmłodsi użytkownicy mieli przyjmować wadliwe z punktu widzenia społecznego wzorce zachowań, a sieć miała prowadzić do osamotnienia czy powodować „wirtualny autyzm” (Heffler, Oestreicher 2016).

Problemem empatii po raz pierwszy zajęto się w ramach psychoanalitycznej koncepcji osobowości (Wojciszke 2004; Aronson 2000; Reykowski 1979), gdize definiowano tę kategorię jako czynnik regulujący zachowanie jednostki wobec przedmiotu identyfikacji. Innym sposobem rozumienia empatii są rozważania, dla których inspiracją stały się stwierdzenia Jeana Piageta (Piaget 2012) dotyczące stopnia dojrzałości i organizacji struktur poznawczych, rozważanych w kategoriach zdolności do podejmowania roli innej osoby. Współcześnie wyróżnia się empatię emocjonalną, poznawczą i emocjonalno-poznawczą. Głównym kryterium podziału jest geneza rodzajów empatii, a nie jakość czy kolejność procesów psychicznych lub różnice mechanizmów ich działania. W stanowisku reprezentowanym przez Janusza Reykowskiego (1979) empatia emocjonalna rozumiana jest jako reakcja emocjonalna wywołana przez dostrzeganie cudzych uczuć. Umożliwia ona: doświadczanie cudzych emocji jako własnych, współ- 
odczuwanie, czyli przenoszenie na siebie cudzych emocji, współczucie, a więc emocjonalną reakcję na uczucia innej osoby, uwzględniającą jej stan i zorientowaną na nią. Empatia poznawcza jest zaś procesem, który polega na stawianiu się w czyimś położeniu, a w związku z tym - na trafnym postrzeganiu cudzych reakcji. Empatię poznawczą utożsamia się niekiedy z umiejętnością wejścia w sytuację poznawczą i rolę społeczną innej osoby oraz z trafnością interpersonalną.

W tym ujęciu wzrost popularności internetu wśród użytkowników, których osobowość i tożsamość są w trakcie kształtowania, to fakt niezwykle interesujący. Oczywiście, globalna sieć oparta na technologiach informacyjnych nie jest pierwszym medium, które działa jako element pośredniczący w procesach socjalizujących, ale ze względu na interaktywność i szybką popularyzację tego narzędzia, a przez to uzupełnianie oraz wypełnianie wcześniejszych form (pismo, radio, telewizja), to ono zasługuje na największe zainteresowanie we współczesnej refleksji intelektualnej.

Wnioski zawarte w studium Changes in dispositional empathy in American college students over time: a meta-analysis (Kornath i in. 2010) pozwoliły przyjąć hipotezę, że na znaczny spadek postaw empatycznych wśród amerykańskich studentów miał wpływ właśnie rozwój internetu. W myśl tej interpretacji relacje online, w przeciwieństwie do tych ze świata fizycznego, są powierzchowne i przez to uniemożliwiają harmonijny rozwój osobowości w stronę zachowań empatycznych.

Hipoteza ta spotkała się jednak z krytyką w kolejnych latach. Szczególnie godna uwagi jest publikacja Virtual empathy: positive and negative impacts of going online upon empathy in young adults (Carrier i in. 2015), której autorzy na podstawie badań ankietowych przeprowadzonych na młodych dorosłych dowodzą, że alarmistyczne głosy o upadku empatii w czasach cyfrowych są przesadzone. Według nich użytkownicy internetu wykazują się zachowaniami empatycznymi - zarówno w świecie rzeczywistym, jak i online. W wypadku relacji zapośredniczonych przez sieć, „internetowa” empatia w relacjach międzyludzkich występuje jednak w wersji słabszej niż w relacjach „twarzą w twarz". Przestrzeniami, w których postawy empatyczne są wyraźnie słabsze, są konkretne formy aktywności (takie jak gry komputerowe). Innymi słowy, wpływ współczesnych technologii komunikacyjnych na postawy nie różni się radykalnie od wcześniejszych mediów: telewizji, radia czy pisma. 
Problemy - zgodnie z hipotezą tłumaczącą korelację częstego korzystania z mediów społecznościowych ze spadkiem "skończonych zasobów" czasowych - pojawiają się dopiero wtedy, kiedy interakcje online zastępują relacje międzyludzkie niezapośredniczone przez technologie. Ma to duże znaczenie z punktu widzenia nauk o wychowaniu, gdyż $\mathrm{z}$ jednej strony istnieje niebezpieczeństwo zaprzepaszczenia dorobku socjalizacyjno-wychowawczego realizowanego w środowisku rodzinnym i szkolnym, z drugiej zaś pojawia się szansa na korektę procesów wychowawczych wtedy, gdy w realnym życiu młodych ludzi nie są one właściwie realizowane.

Pojawiają się zatem pytania:

$\rightarrow$ Czy można być empatycznym wobec całej zbiorowości ludzkiej, która jest w sieci?

$\rightarrow$ Kto jest naprawdę bliski emocjonalnie - osoby, z którymi często się komunikujemy, ale ich nie znamy, czy rodzina i koledzy oraz koleżanki z klasy?

$\rightarrow$ Czy rozwijając relacje zapośredniczone przez sieć, zachowujemy się tak samo jak "twarzą w twarz", a jeśli nie, to która z tych emocji jest realnie uprawdopodobniona?

Wobec takich dylematów należałoby opracować odpowiednie metody i techniki socjalizacyjno-wychowawcze, które mogłyby zastąpić lub uzupełnić funkcjonowanie tych procesów w warunkach rzeczywistości poszerzonej. Jak widać z pobieżnej analizy, problem sam w sobie jest interesujący i powinien doczekać się dalszych eksploracji empirycznych. Powstające $w$ tym miejscu pytania dotyczące granic empatyczności i jej uwarunkowań psychospołecznych wymagają przygotowania odpowiedzi.

Osobną kwestią poruszaną przez badaczy, pedagogów i rodziców w związku z coraz większą dostępnością i popularnością technologii cyfrowych wśród dzieci są problemy związane z zachowaniami agresywnymi. Od początku zwracano uwagę na wpływie brutalnych gier komputerowych na graczy, koncentrując się na treściach traktujących przemoc fizyczną jako rozrywkę. Badacze próbowali wytłumaczyć ten fenomen także psychofizycznymi konsekwencjami długotrwałego przebywania przed ekranem i skupiania uwagi w nienaturalny (ze względu na ewolucyjne uwarunkowania) dla człowieka sposób (Ko i in. 2009). Współczesne badania potwierdzają te intuicje. Świadczą o tym między 
innymi wyniki eksperymentów laboratoryjnych, potwierdzające wzmocnienie zachowań agresywnych rejestrowane bezpośrednio spędzaniu czasu nad grami wideo (Kühn i in. 2018). Metabadania longitudinalne (Anderson i in. 2010) także potwierdzają związek między częstym graniem w brutalne gry a zachowaniami antyspołecznymi i agresywnymi. Według autorów tych analiz wpływ jest niezaprzeczalny, wątpliwości zaś istnieją jedynie w obszarze interpretacji tego zjawiska. W 2015 r. American Psychology Association, opierając się na wynikach badań, opublikowało apel do rodziców, opiekunów, edukatorów i pedagogów oraz instytucji, wzywając do większego zaangażowania się w zwalczanie nadmiernej brutalizacji gier oraz w przeciwdziałania zbyt długiemu czasowi poświęcanemu przez młodzież na granie ${ }^{9}$.

Osobną kwestią związaną z problematyką agresji w sieci jest łatwy dostęp użytkowników do treści niebezpiecznych, a co za tym idzie - do wzorców zachowań agresywnych. W ostatnich latach, wraz z rozwojem algorytmów opartych na sztucznej inteligencji, zwiększają się możliwości ukrywania przez filtry sieciowe niebezpiecznych treści. Mechanizmy te jednak wciąż nie są doskonałe. Dzieci i młodzież ciągle, przeważnie przypadkowo, trafiają na strony z niezwykle brutalnymi czy demoralizującymi treściami. Często są to materiały nielegalne i szkodliwe, na przykład nagrania egzekucji, dziecięca pornografia czy filmy pokazujące znęcanie się nad zwierzętami. Pracujący w ramach Naukowej i Akademickiej Sieci Komputerowej zespół Dyżurnet.pl w 2017 r. otrzymał i przeanalizował prawie 14 tysięcy ${ }^{10}$ zgłoszeń w tych sprawach.

W ostatnim czasie o problemie agresji było głośno w związku z fenomenem „inceli”, czyli komunikujących się ze sobą w internecie (przeważnie młodych) mężczyzn, którzy propagują wzajemnie idee określane jako antykobiece i antyfeministyczne (Zambrzycka-Kościelnicka 2018). O tym terminie zrobiło się głośno w 2018 r., kiedy Alek Minassian, dwudziestopięcioletni mieszkaniec Toronto w Kanadzie, dokonał zamachu terrorystycznego przy użyciu furgonetki, zabijając dziesięć osób11. O ile nie ma wielu przykładów realnej fizycznej agresji ze strony osób identyfikujących się z ruchem „inceli", o tyle sytuacja obrazuje łatwość, z jaką 
internetowe wspólnoty mogą wpływać na swoich członków. Nawet w wypadku niewielkiej liczby osób o poglądach radykalnych współczesne technologie informacyjne dzięki usieciowieniu mogą wzbudzić w nich przekonanie o powszechności danego światopoglądu i postaw. Internet to także narzędzie, które może wpłynąć na radykalizację postaw osób o zaburzonych parametrach socjalizacyjnych, samotnych czy zmagających się z problemami natury życiowej, emocjonalnej lub psychicznej.

Zaprezentowane skutki „sieciowych" wpływów socjalizacyjnych, ze szczególnym uwzględnieniem mechanizmów kształtowania parametrów społecznej i osobowej sylwetki człowieka w świecie wirtualnym, wchodzą w nieustanny dialog z wpływami wychowawczymi, przeplatając się zakresowo i jakościowo. Dlatego ludzkie tożsamości w toku rozwoju jakościowego uwarunkowane są tymi wpływami, a wynik tych wpływów współdecyduje w znacznym stopniu o funkcjonowaniu jednostki w wymiarach indywidualnym i społecznym, zarówno w świecie realnym, jak i w rzeczywistości internetu.

Z punktu widzenia teorii psychologicznych i pedagogicznych mechanizmy socjalizacyjne mają wymierny wpływ na kształtowanie się zachowań agresywnych oraz na rodzaj agresji. Parametry brzegowe odgrywanych ról społecznych wypełnionych treścią tożsamościową wyznaczają określone i społecznie akceptowane ramy ludzkich zachowań. Agresja interpersonalna przekraczająca te ramy jest istotnym problemem społecznym i postępowanie resocjalizacyjne w dużej mierze nastawione jest na jej niwelowanie.

Najczęściej spotykana i najbardziej pojemna definicja agresji stanowi, że jest to zachowanie nastawione na zadawanie cierpienia innemu człowiekowi, który jest motywowany do uniknięcia tego cierpienia (Barron 1969). Biologiczne koncepcje człowieka doszukują się źródeł agresji w dynamicznych siłach tkwiących w naturze ludzkiej. Teorie te traktują agresywne zachowanie się i związane z nim przeżycie gniewu jako objaw wrodzonego instynktu walki. Pogląd taki podzielał między innymi William McDougall (Aronson i in. 1997), który twierdził, że zachowaniem człowieka kieruje wiele instynktów, jednym z najważniejszych jest instynkt walki. Stanowi on źródło uczuć gniewu, które są impulsem powodującym pojawienie się różnic w zachowaniach agresywnych.

Gniew powstający na podłożu tego instynktu jest, zdaniem Williama McDougalla, zjawiskiem pozytywnym z biologicznego punktu widze- 
nia, gdyż pobudza osobnika do zdobycia zasobów potrzebnych mu do zaspokojenia potrzeb, skłania do obrony przed atakami oraz umożliwia utrzymanie dotychczasowego stanu posiadania. Gniew może być wywołany wieloma różnymi podnietami związanymi z doznawanymi niepowodzeniami, które stają się przez to impulsami powodującymi wystąpienie agresywnych zachowań.

Sigmund Freud (1976) teorię agresji oparł na założeniach psychoanalitycznych. Uważał, że osobowość człowieka składa się z trzech składników: „id”, „ego" i „superego". Konflikty powstające między tymi składnikami są powodem frustracji, która pobudza do agresji skierowanej przeciw osobom lub przedmiotom. W końcowej fazie działalności naukowej Freud zajął się głównie instynktem życia i instynktem śmierci. Sprzeczność zachodzącą między tymi instynktami uważał za źródło zachowań agresywnych.

Przedstawiciele psychoanalitycznego podejścia do agresji (między innymi Alfred Adler) przyjmowali również istnienie wrodzonego, uwarunkowanego genetycznie instynktu agresji, który występuje samodzielnie i - obok instynktu płciowego - stanowi główną siłę napędową ludzkiego działania. Skłonność do agresji tkwi potencjalnie w organizmie, frustracja zaś może stwarzać jedynie warunki sprzyjające jej wyzwoleniu się i manifestowaniu na zewnątrz. Nieco odmienne zdanie na temat agresji mają ci zwolennicy psychoanalizy, którzy odrzucają istnienie wrodzonego instynktu agresji i twierdzą, że u człowieka dominują wrodzone instynkty społeczne. Agresja wyzwala się wówczas, gdy instynkty społeczne ulegają zahamowaniu lub z pewnych powodów nie mogą być zaspokojone.

Fizjologiczna teoria agresji szczególne znaczenie przypisuje zarówno podwzgórzu, jak i korze mózgowej. Te dwie części mózgu funkcjonują antagonistycznie. Pobudzający wpływ procesów zachodzących w podwzgórzu odgrywa istotną rolę w powstawaniu gniewu i towarzyszącemu mu agresywnemu zachowaniu, z kolei procesy hamowania korowego mogą neutralizować stan pobudzenia powstały w podwzgórzu. Pobudzenie układu sympatycznego oraz odpowiednich narządów wewnętrznych ma charakter wtórny i jest rezultatem działania impulsów nerwowych pochodzących z obwodowego układu nerwowego, które nie powstają spontanicznie, lecz są następstwem oddziaływania na organizm określonych podniet zewnętrznych. 
Behawiorystyczne badania agresji dotyczą zachowań dających się ująć w schemat bodziec - reakcja. Nagradzane reakcje agresywne utrwalają się, co powoduje wytwarzanie się odpowiednich nawyków dotyczących tego typu zachowań, jeśli zaś są karane, ulegają zahamowaniu i wygasają. Nabywanie nowych doświadczeń życiowych prowadzi do stopniowego różnicowania podniet, w rezultacie czego pobudzający lub hamujący wpływ na agresywne zachowanie mają jedynie ściśle określone (nie podobne) rodzaje nagród i kar.

Behawioryści udowodnili również istnienie zależności między agresywnym zachowaniem a pewnymi warunkami środowiskowymi. Stwierdzono, że agresywne zachowanie się członków grupy oraz anonimowość poszczególnych osób działających w tej zbiorowości wpływają pobudzająco na występowanie tego rodzaju zachowań. Jednostka przejawia agresję wtedy, gdy działa wspólnie z grupą, która dostarcza jej wzorów takiego zachowania, aprobuje je, zapewnia jej anonimowość. Czynniki o charakterze społecznym (na przykład występujące w otoczeniu wzory pozytywnego zachowania się i powszechna dezaprobata wobec przemocy) mogą nie tylko pobudzać agresję, ale i jej przeciwdziałać. Behawioryści potwierdzali również istnienie czynników wrodzonych, które mogą mieć wpływ na intensywność i częstość występowania reakcji agresywnych.

Zjawisko agresji, zarówno w świecie realnym, jak i w rzeczywistości wirtualnej, ma pozornie wiele wspólnych cech. Dominująca perspektywa behawioralna dotycząca tego typu zachowań nie zawsze jest jednak adekwatna w odniesieniu do przestrzeni internetowej. O ile agresja i agresywność w rozumieniu koncepcji behawioralnych mają często znaczenie przystosowawcze i obronne w realnym życiu codziennym, to w rzeczywistości poszerzonej takich znaczeń nie można odszukać. Możemy raczej mówić o instrumentalnej agresji dezadaptacyjnej, ukierunkowanej na zrobienie komuś bezinteresownej krzywdy. Podobnie jednak jak w wypadku empatii, problem agresji w procesie socjalizacji przebiegającej w sieci internetowej wymaga przeprowadzenia dokładniejszych analiz i pogłębionych badań empirycznych. Nie da się klasycznych definicji uwarunkowań i objawów tego zjawiska występującego w świecie rzeczywistym bezrefleksyjnie przenosić do środowiska internetu, z czym mamy często, niestety, do czynienia. Duża część osób piszących o problemie agresji w sieci stosuje tradycyjne sposoby rozumienia tego zjawiska 
i próbuje dostosowywać takie koncepcje do przestrzeni rzeczywistości poszerzonej. Nie jest to zabieg w pełni uzasadniony.

Z wpływem internetu na zjawiska agresji i empatii związana jest immanentnie tematyka ludzkich zachowań autoprezentacyjnych. Media społecznościowe, które można opisać jako wirtualne platformy oparte na behawioralnym wynagradzaniu za udane akty autoprezentacji (Davidow 2013) - liczba znajomych i polubień, zasięg publikowanych treści - wykorzystują ludzkie pragnienie społecznej akceptacji w celach biznesowych, czyli przynoszenia zysku akcjonariuszom. Z punktu widzenia ekonomicznego w interesie właścicieli portali leży, aby użytkownicy jak największą część czasu spędzali na tworzeniu cyfrowych wyrazów autoprezentacji. To właśnie aktywność, uwaga i przejawy zachowań autoprezentacyjnych użytkowników są - w formie danych osobowych - towarem, który właściciele stron, aplikacji i portali sprzedają lub udostępniają reklamodawcom, instytucjom finansowym, badaczom czy instytucjom rządowym.

W warstwie teoretycznej należy zwrócić uwagę, że autoprezentacje w przestrzeni internetu mogą mieć charakter adekwatny lub nieadekwatny do sytuacji, a także mogą w pełni lub w wersji ubogiej w treści wyrażać "ja" użytkownika. Podstawowym czynnikiem dotyczącym autoprezentacji są cele wyznaczane przez kierunki pojawiających się potrzeb, z drugiej zaś strony - sposoby osiągania zakładanych celów, uwarunkowane cechami doświadczeń socjalizacyjnych. Osiąganie celów odbywa się dzięki skryptom i planom jednostek zapośredniczonych przez możliwości techniczne dostarczone przez platformę komunikacji (na przykład aplikację lub serwis).

Można powiedzieć, że funkcjonowanie skryptów przypomina działania programu komputerowego, który uruchomiony, już samoistnie, bez udziału użytkownika, osiąga założone cele. Związek założonego celu i powiązanego z nim skryptu lub planu określamy jako dążenie (Baumeister 1986). Kontakty międzyludzkie wymagają podtrzymywania i prezentowania względnie spójnej tożsamości. Społeczne interakcje, w których bierze udział również młodzież, wymagają od niej zachowań zgodnych z przyjętymi rolami społecznymi.

Młodzi ludzie tworzą skrypty, które są ściśle powiązane z ich koncepcją tożsamości, dlatego nie zawsze potrafią lub mogą odgrywać - akceptowane treścią - wymagane od niej role. Prezentując się innym, zarówno w świecie realnym, jak i w internecie, ludzie przedstawiają 
parametry własnej tożsamości, tworząc swój publiczny wizerunek. Wizerunek ten rzutuje bezpośrednio na jakość relacji interpersonalnych oraz określa miejsce w stratyfikacji społecznej. Osoby wadliwie zsocjalizowane, posiadające ograniczony kod językowy, wywierają na ogół złe wrażenie na innych. Wrażenie to wpływa na zwiększanie dystansu społecznego oraz poczucia dyskomfortu i izolacji interpersonalnej u niektórych osób. Nie są one na ogół świadome przyczyn takiego stanu rzeczy, a swoje nieadekwatne sytuacyjnie reakcje (agresja, wycofanie się) usprawiedliwiają przyczynami zewnętrznymi (postawą otoczenia wobec nich). Trudno im zrozumieć, że na taki stan rzeczy ma wpływ ich sposób prezentowania się.

Sytuacyjne i planowane przedstawianie innym osobom swoich cech nosi znamiona autoprezentacji. Zachowania autoprezentacyjne w zasadzie ujawniają prawdziwe informacje o osobie. Stosunkowo rzadko w typowych sytuacjach społecznych świata rzeczywistego spotyka się przykłady tworzenia nieprawdziwych wizerunków publicznych. Niewątpliwie jednak zjawisko to dotyczy ludzi, dla których efekt autoprezentacyjny ma odegrać określoną rolę - można wśród nich wymienić między innymi profesjonalnych oszustów, aktorów czy polityków. Jeśli schemat autoprezentacji jest względnie trwały, cyklicznie powtarzalny oraz identyfikowalny kontekstowo, można mówić o zjawisku wizualizacji parametrów tożsamościowych (Konopczyński 2007).

Autoprezentacja jest celowym działaniem ukierunkowanym na wywołanie w otoczeniu społecznym pożądanego przez daną jednostkę wizerunku własnej osoby (Szmajke 1999). Jest to więc specyficzna forma wywierania wpływu społecznego, a nawet - jak podkreślają niektórzy autorzy - sposobem manipulowania innymi ludźmi. Ludzkie motywacje do modyfikowania swojego obrazu zależą od wagi osiąganych celów, są zaś motywowane przekonaniem o występowaniu zależności pomiędzy wywieranym wrażeniem a podjętym działaniem oraz rozbieżnością między prezentowanym wizerunkiem a jego odbiorem społecznym (Leary 2004).

Erving Goffman zauważył, że warunkiem istnienia interakcji społecznych jest konstruowanie przez ludzi publicznych wymiarów ich tożsamości. Tak więc społeczne parametry tożsamości umożliwiają kontakty interpersonalne i tworzą ramy tworzonych ról życiowych. Dotyczy to w takim samym stopniu osób określanych jako "normalne”, jak i jednostek wykazujących daleko idące zaburzenia w zachowaniach 
i postawach społecznych. Krańcowo odmienne będą tylko wewnętrzne i zewnętrzne czynniki oraz mechanizmy uruchamiające schematy strukturalne parametrów tożsamościowych obu kategorii ludzi. Można hipotetycznie założyć, że młodzi ludzie podejmują swoje autoprezentacje w przestrzeni internetu z różnych powodów, takich jak:

$\rightarrow$ Ochrona (kontakty na poziomie środowiska podkulturowego) lub zwiększenie poczucia własnej wartości (kontakty z ludźmi mającymi dla nich znaczenie, a pochodzącymi spoza środowiska podkulturowego).

$\rightarrow$ Ukształtowanie wartościowych, z ich punktu widzenia, relacji interpersonalnych, zaspakajających ich potrzeby psychologiczne.

$\rightarrow$ Wywieranie manipulatywnego wpływu na otoczenie, potwierdzające ich domniemane znaczenie społeczne (wynika to z zaniżonego poziomu samooceny).

$\rightarrow$ Podtrzymywanie i tworzenie własnej tożsamości lub niektórych cech (Leary, Kowalski 1990; Goffman 2000; Szmajke 1999). Kategoria ta jest szczególnie istotna w naszych rozważaniach. W wypadku wielu osób będą to na ogół rejestry negatywnych cech i nieakceptowanych społecznie atrybutów, dlatego ich tożsamość stanowi dla nich samych barierę ograniczającą rozwój wewnętrzny i społeczny. Jednocześnie takie osoby nie są w stanie nic z tym faktem zrobić, gdyż autoprezentacja ich tożsamości przebiega automatycznie, zgodnie $z$ wyuczonymi schematami socjalizacyjnymi.

Można przyjąć, że forma i treści ról odgrywanych przez młodzież to wypadkowa sytuacji społecznych, w których młodzi ludzie uczestniczą, oraz sposobów i form ich autoprezentacji. W ten sposób parametry tożsamościowe (zbiory charakterystycznych cech "ja" indywidualnego i społecznego) uniemożliwiają im poprawne i akceptowane funkcjonowanie w rolach i doprowadzają do zawężenia kręgu ich kontaktów oraz obniżenia poziomu jakości relacji interpersonalnych.

Analizując zjawisko tworzenia parametrów tożsamości w sieci, powinniśmy to zagadnienie uwzględniać w kategoriach norm autoprezentacyjnych. Mogą mieć one charakter preskryptywny, czyli określający, jakiego rodzaju wrażenie należy wywierać na otoczeniu społecznym, lub charakter restrykcyjny, ograniczający zakres i treści autoprezentacji. Istotną rolę w kształtowaniu zarówno umiejętności identyfikowania 
społecznych okoliczności funkcjonowania norm autoprezentacyjnych, jak i stosunku do nich, odgrywają procesy socjalizacyjne. Można przyjąć, że osoby stosujące się do norm autoprezentacyjnych przeszły właściwy proces socjalizowania, ostatecznie więc tworzony przez nie wizerunek (i jego odbiór przez otoczenie) jest zgodny z ich intencjami. Jeśli jednak jednostki wadliwie socjalizowane mają problemy z identyfikacją tej kategorii norm, to ich wizerunek kreowany jest niezgodnie z intencjami.

Normy autoprezentacyjne, czyli kontekstowe wzory sposobów wywierania wrażenia społecznego, zależą od wielu czynników. Do najważniejszych z nich możemy zaliczyć kulturę dominującą w danym typie środowiska, warunki cywilizacyjne i społeczne, obowiązujące regulacje prawne, wpływy religijne i światopoglądowe oraz obecną ideologię polityczną. Są to więc te kategorie, które należą do tradycyjnych sfer zainteresowania pedagogiki. Kształtowanie i wizualizacja parametrów tożsamości wynika w dużej mierze z tych ograniczeń i uwarunkowań, dlatego proces ten ma charakter działań kontekstowych, biorących pod uwagę zależności kulturowo-społeczne i wynikające z nich konsekwencje.

Jednym z głównych czynników psychospołecznych utrudniających lub wręcz uniemożliwiających poprawne funkcjonowanie w rolach społecznych i życiowych wielu osób jest zjawisko stygmatyzacji. Polega ono na "ustawieniu" jednostki w jej rolach przez otoczenie społeczne. Tworzący się wówczas dystans interpersonalny o charakterze percepcyjno-emocjonalnym skutkuje wewnętrznym przekonaniem osób funkcjonujących dewiacyjnie, że środowiska, w których przebywają, "odcinają się" od nich i nie chcą z nimi utrzymywać relacji. Szansą na odwrócenie tego zjawiska jest zainicjowanie procesów destygmatyzacyjnych, które są możliwe do realizacji w umożliwiającym zachowanie anonimowości świecie internetu.

Socjalizacja w sieci może przebiegać podobnie jak w naturalnym środowisku rodzinnym, ale może wywołać zdecydowanie inne skutki ze względu zmianę środowiska technologiczno-kulturowego. Podstawową różnicę stanowią tu czynniki temporalne i czynniki biologiczno-fizykalistyczne - nie da się w przestrzeni internetowej zaspokajać ludzkich potrzeb pierwszego rzędu, które mają ogromny wpływ na nasze emocje i poczucie bezpieczeństwa. Kontakt interpersonalny w rodzinie jest praktycznie nieograniczony czasowo, a w przestrzeni internetu istnieją obiektywne, niezależne od nas samych granice. Wydaje się więc wielu 
osobom, że socjalizacja w rodzinie jest nie do zastąpienia socjalizacją

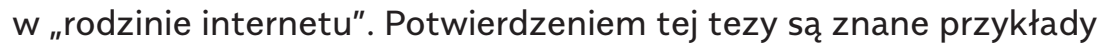
osób izolujących się w relacjach interpersonalnych w środowisku naturalnym (na przykład rodzinnym czy szkolnym), a aktywizujących się $w$ relacjach internetowych. Obserwacja takich osób wskazuje, że ograniczenie do minimum realnych kontaktów z osobami z najbliższego otoczenia skutkuje problemami natury emocjonalnej i psychofizycznej, nie ma jednak negatywnego wpływu na rozwój intelektualny. Być może jest to prawidłowość cywilizacyjna, prowadząca do wyobcowania kolejnych pokoleń z realnych kontaktów międzyludzkich na rzecz kontaktów zwirtualizowanych i pozbawionych rozpoznawalnych do tej pory kategorii emocji.

\section{Socjalizacja w sieci szansą czy przekleństwem naszych czasów?}

Przeanalizowany skrótowo w niniejszym artykule problem socjalizacyjnej i wychowawczej „mocy” internetu skłania nas do stwierdzenia, że z punktu widzenia teorii społecznych i pedagogicznych zakres naszej niewiedzy jest obszarowo i jakościowo większy niż zdobytej wiedzy (która ma charakter spekulatywny i probabilistyczny). Można uznać, że dotychczasowe pedagogiczne rozumienie rzeczywistości społecznej oparte na myśleniu paradygmatycznym, przyjętym i sfalsyfikowanym w XX w., wymaga przemyślenia i korekt, nie mieści się bowiem w skomplikowanej materii połączenia dwóch zachodzących na siebie światów: świata realnego, materialistycznego, i świata wirtualnego, silnie zmediatyzowanego. Trudno jednoznacznie stwierdzić, czy paradygmaty humanistyczny i interpretatywny, stosowane przez pedagogiczne środowiska akademickie XXI w., są adekwatne do postrzegania i interpretowania złożonej rzeczywistości świata internetu, który zawiera aspekt czysto techniczny, a więc powinien podlegać interpretacjom o znamionach strukturalistycznych lub funkcjonalistycznych, nie zaś humanistycznych czy interpretatywnych.

Mamy zatem do czynienia z zupełnie nowym zjawiskiem percepcji społecznej, a więc postrzegania, analizowania i oceniania otaczającej rzeczywistości. Socjalizacja przenosi się z poziomu dotychczasowych utartych schematów intelektualnych i środowiskowych na obszar wciąż niewystarczająco opisany, będący przedmiotem sporów i dyskusji. 
Warto pamiętać, że dopiero od niedawna media - pismo, radio, telewizja czy internet - mają charakter masowy w skali świata. Człowiek, czyli "wytwór" biologii i kultury, dotychczas traktował technikę przede wszystkim jako sposób ułatwiania sobie życia i zaspokajania potrzeb niższego rzędu. Dopiero rewolucja informacyjna (wciąż trwająca) sprawiła, że technika nabiera w naszym życiu innego znaczenia i odgrywa w nim dominującą rolę.

Internet jest zatem przejawem nie tylko daleko spersonalizowanej techniki, ale przede wszystkim narzędziem odkrywania nowych wymiarów ludzkiej egzystencji, ze wszystkimi konsekwencjami tego procesu. Jego zastosowanie jako nowego technicznego rozwiązania ułatwiającego zdobywanie informacji i komunikowanie się z innymi ludźmi jest tylko kolejnym krokiem w cywilizacyjnym rozwoju ludzkości. Być może jednak jest czymś więcej - na przykład sposobem realizacji odwiecznego marzenia człowieka o zapewnieniu sobie nieśmiertelności, jak twierdzi Ray Kurzweil (2004) - futurolog i naczelny ekspert do spraw rozwoju w firmie Google. Z punktu widzenia nauk społecznych i pedagogiki wiele pytań dotyczących sieci pozostaje jednak otwartych. Dopiero za kilkanaście lub kilkadziesiąt lat, kiedy wychowane w sieci kolejne pokolenia decydować będą o procesach gospodarczych, technologicznych, kulturowych i politycznych, możliwe będzie dokonanie rzetelnej oceny skutków rozpoczętej w XX w. rewolucji informacyjnej. 